\title{
THE EFFECT OF DISTANCE LEARNING MODEL ON BEGINNERS' LEVEL VIOLIN INSTRUCTION
}

\author{
Dr. Soner OKAN \\ ORCID: https://orcid.org/0000-0001-6749-8163 \\ Faculty of Fine Arts, Music Department \\ Kahramanmaras Sutcu Imam University \\ Kahramanmaras, Turkey \\ Dr. Hasan ARAPGIRLIOGLU \\ ORCID: https://orcid.org/0000-0002-3945-7716 \\ Antalya State Conservatory, Composition and Conducting \\ Akdeniz University \\ Antalya, Turkey
}

Received Date: 07/02/2018 Accepted Date: 19/10/2018

\section{ABSTRACT}

In this study, it was aimed to determine the effect of distance education model on beginners' level violin instruction. To this aim, as the appropriate experimental research model, pre-test-posttest with control group, was used. The study group of consisted of students from State Conservatory of Dicle University (n $=12$ ). Violin classes were given using face-to-face teaching method with control group for 8 weeks; and distance learning method with experimental group for 8 weeks. "Student Academic Achievement Evaluation Form" was used as the tool to collect data for the research. Percentage, mean and standard deviation were used as descriptive statistical methods in evaluating the data. Man Whitney-U test was used to compare quantitative longitudinal data between two independent groups. The Wilcoxon test was used to compare intra-group changes/differences. The findings were evaluated at $95 \%$ confidence interval and at $5 \%$ significance level. As a result of the research, there was a significant difference between the pretest-posttest scores of the beginner group. This difference is seen to be in favor of the posttest. There was a significant difference between the pretest-posttest scores of the control group in favor of posttest. However, there was no significant difference between pretest scores and posttest scores of baseline experimental and control groups. This result showed no significant difference between the traditional face to face instruction and distance instruction in terms of the basic skills acquired by the students.

Keywords: Distance education, distance education model, violin instruction.

\section{INTRODUCTION}

Just as Technological developments affect all aspects of they also lead to rapid changes in education. Performed by using the opportunities provided by technology; it has shifted to an axis of lifelong learning where it is possible to reach the school from everywhere, and it has become a necessity at all ages, rather than being an indoors activity directed at individuals at a certain age. In parallel with this evolving understanding, the increase in the need for learning has started being felt more and more intensely.

Although the violin instruction is regarded within the scope of individual instrument classes, it has also been considered as a form of group instuction because of the increasing number of students and insufficient number of teaching staff. One of the most important problems violin students face is that the limited time 
of instruction. According to Taninmis (2013, p. 713) students receive additional help from the instructor outside the class hours. However, it is very difficult for the lecturer to solve the problems of all students just by doing this. Sever $(2014$, p. 29) stated that the weekly class hours are not sufficient in order for the students to achieve the desired skills on their instrument in educational institutions and due to that time limit, other problems also arise. Even if it seems to be one of the partial/temporary solutions for this problem, increasing number of lessons will not be enough as the number of students' increases and as a result, new buildings, classroom and teaching-staff will be needed.

Tarkum (2006, p. 170) states that there are differences between students in terms of gripping style and aptitude for the instrument. He also adds that a violin student with higher gripping power may have a lower aptitude and it is possible for a student with less aptitute to have a higher gripping power, therefore these differences must be placed in a content that would facilitate them be handled in a balanced manner.

A great majority of students grow without having high quality arts education. Factors such as transportation, limited number of instructors and educational costs make it difficult for the individual to establish and maintain a contact with fine arts. For many years, individual's involvement in artistic activities have depended on his area of residence. With the widespread use of the Internet, the computer screen functions as a classroom for individuals with limited opportunities to learn to play an instrument. A distance learning model of violin instruction could give all members of a society the opportunity to keep in touch with with fine arts. In this way, the students who have already had violin instruction can continue their training out of the classroom. By learning how to use technology for violing instruction, it is possible to create flexible and non-restricted learning environments for students.

The distance education model is seen as a solution for the problems encountered in violin instruction, it is also considered as a very effectivein promoting individual learning, and is thought to be sufficient as a standalone instructional model. The purpose of this research is to determine the effects of the distance learning model on violin instruction.

\section{PROBLEM STATEMENT}

The problem statement of the study is that "To what extent the distance learning model has an effect on beginning level violin instruction?"

\section{Research Hypotheses}

The research hypothesis is as follows:

$>\mathrm{H}_{0}$ : There is no significant difference between pretest-posttest scores of the experimental group at the beginners level.

$>\mathrm{H} 1$ : There is a significant difference between the pretest-posttest scores of the experimental group at the beginners level

$>\mathrm{H}_{0}$ : There is no significant difference between the pretest-posttest scores of the control group at the beginners level

$>\mathrm{H} 1$ : There is a significant difference between the pretest-posttest scores of the control group at the beginners level.

$>\mathrm{H}_{0}$ : There is no significant difference between the pretest-posttest mean scores of the experimental and control groups at the beginners level.

$>$ H1: There is a significant difference between the pretest-posttest mean scores of experimental and control group at the beginners level 


\section{Purpose of the Research}

The aim of this research is:

$>$ To determine whether there is a significant difference between the group trained with distance eucation education is $\mathrm{p}$ and the group where face to face instruction is applied,

$>$ To demonstrate the effect of distance education model on student achievement,

$>$ To make contributions to violin education by proving the effectiveness of a distance education model created for violin instruction.

\section{The Importance of Study}

This study is important for providing opportunities for violin students training by using distance education;

$>$ To develop a sense of responsibility by taking more responsibility for learning,

$>$ To be able to continue their education outside the classroom environment using the materials prepared for distance education,

$>$ To develop their self-learning skills,

$>$ It is also important in terms of gaining life-long learning skills by learning to learn.

In addition to these achievements, it seems to be very important for the students:

$>$ To make learning more permanent by offering them learning environments enriched with various tools and equipments.

$>$ To decrease instructional costs such as transportation, staff, stationery,

$>$ To ensure that time is used more efficiently through distance learning,

$>$ Especially in our country- to provide the highest level of utilization of technological facilities by offering a new teaching model for violin instruction.

\section{METHOD}

In this section, information regarding the experimental design, the study group, assignment of participants into control and experimental groups, the preparation of the instructional programme, the data collecting tools and the analysis of the data will be given.

\section{Model of Research}

In a study, experimental method is generally used to measure variables and to reveal the cause-effect relationships between them. The most appropriate research method that can be used to investigate the causeand-effect relationship between variables is the experimental method. In the experimental method, participants with equal features are assigned to control and experimental groups. During the experiment, no treatment is made to the control group while special actions are taken for the experimental group. The effectiveness of the method used in control group is investigated with pre-test and post-test at the end of the study (Cepni, 2009: 113). Having a quasi-experimental structure using pre-test post-test model with a control group, this study aims to determine the effects of distance education model on violin instruction.

Table 1: Research method and the experimental design

\begin{tabular}{cllccc}
\hline & Group & Neutrality & Pretest & Treatment & Posttest \\
\hline $\begin{array}{l}\text { Experimental } \\
(\mathrm{n}=6)\end{array}$ & group & $\begin{array}{l}\text { Random } \\
\text { Assignment }\end{array}$ & $\mathrm{x}$ & Distance Learning & $\mathrm{X}$ \\
& $\mathrm{X}$ & Face to Face Instr. & $\mathrm{X}$ \\
& $\begin{array}{l}\text { Random } \\
\text { Assignment }\end{array}$ & $\mathrm{X}$ & & \\
\hline
\end{tabular}

\section{Study Group}

Purposive sampling method was preferred as the sampling method in this study. The reason for using this method is to investigate the effectiveness of beginners' and intermediate level distance violin instruction. 
According to Patton (2002), qualitative researchers neither work with large groups nor make generalizations enough to make random selection meaningful. "Interpretive researchers choose each situation for a purpose. The purposive sample allows the selection of information-rich situations for further studies "(Glesne, quoted from 2014; Topalak, 2016, p. 56).

The study group of consisted of 12 students from Dicle University State Conservatory. The students who had never studied violin before were included in the beginners' level control and experimental groups. For 8 weeks control group received face to face violin instruction and the experimental group was instructed by using distance instruction.

\section{Assignment of Control and Experiment Groups}

In establishing the experimental and control group experimental and control groups, interpretability of the changes by creating groups with similar scores were taken into account. After the pre-test skill scores of the students were calculated, the skill scores were put into an order to form an experimantal and a control group.

Table 2. The difference of pre-test scores between the experimental group and control group

\begin{tabular}{|c|c|c|c|c|c|c|}
\hline & \multicolumn{2}{|c|}{ Experimental } & \multicolumn{2}{|l|}{ Control } & \multirow[t]{2}{*}{ MW } & \multirow[t]{2}{*}{$\mathrm{p}$} \\
\hline & Mean & $\mathrm{Sd}$ & Mean & $\mathrm{Sd}$ & & \\
\hline Pretest-Posture and Grip & 9,389 & 5,272 & 10,278 & 4,828 & 14,500 & 0,575 \\
\hline $\begin{array}{l}\text { Pretest -Right Hand and Left } \\
\text { Hand Technique }\end{array}$ & 1,833 & 2,373 & 1,167 & 1,090 & 16,000 & 0,746 \\
\hline Pretest -Performance & 0,000 & 0,000 & 0,000 & 0,000 & 18,000 & 1,000 \\
\hline Pretest -Musicality & 0,000 & 0,000 & 0,000 & 0,000 & 18,000 & 1,000 \\
\hline Pre-test Total & 11,222 & 7,536 & 11,444 & 5,447 & 16,000 & 0,749 \\
\hline
\end{tabular}

The difference between the group averages obtained as the result of the Mann Whitney- $U$ test to determine whether the students' posture and grip pretest, right and left hand technique pretest, performance pretest, musicality pretest and total pretest scores differs in terms of the group variable was not statistically significant p> 0.05).

\section{Preparation of the Instructional Program}

To prepare the instructional program for the study, instructional programs for Instument I (violin) used in Dicle University State Conservatory, Department of Basic Sciences, and the instructional program used in the subject named Turkish and Western instruments (Violin) were utilized.

An Expert Opinion Form form has been established at the stage of preparation of the curriculum. The form consists of 8 items and is in the form of a 5 point likert scale. This form is designed to determine the suitability of the distance education program for its' purpose. As a result of the assessments of the experts interviewed, the "Scope Validity Index" for each of the items in the form was calculated and found to be over 0.90 for all items. For this reason, no changes were made to the curriculum. A Form for Opinions Related to the Musical Works Used was established to determine whether the works to be used in the research include the target behaviors associated with the achievements in the curriculum and opinions were obtained from expert violinists in the field. Analysis of the assessment made by the field experts showed that the "Scope Validity Index" was over 0.90 for all items.

\section{Experimental Procedure}

The experimental procedure was carried out by using the technological facilities of Dicle University, Center for Application and Research in Distance learning. In line with the curriculum, the Learning Management System (LMS) was made accessible to the students by loading the necessary materials. Thus, the students 
had access to course materials through asynchronous communication. These materials have been diversified into written, audio and visual materials. Student-teacher communication is provided via the LMS on a definite day and time of the week (synchronous communication). The introduction, development and conclusion activities of face-to-face violin instruction were transferred into distance instruction and applied via synchronous communication in distance education.

\section{Data Collecting Tools}

For the evaluation of the pre-test and post-test achievement, three different field experts were chosen. In detecting student achievement, and the evaluation errors are minimized by using the experts' scorings. Scoring is made by the experts according to the criteria in the academic achievement evaluation form are evaluated by taking their mean values. The Student Academic Achievement Assessment Form was prepared by using the Turkish and Western Music Instruments Teaching Program for violin and the Performance Assessment Form for Violin Instruction developed by Doger (2016) were used. This form is composed of 4 dimensions and totally 19 items. These dimensions are posture and grip (5 items), right hand-left hand technique (6 items), performance ( 5 items) and musicality (3 items). The form was reviewed and reorganized by three field experts. "One of the logical ways to test the validity of content is to seek expert advice. The expert isExpected to evaluate the items in the draft form of the test in terms of their content "(Buyukozturk, 2011, pp. 168). The Expert Feedback Form was adapted by Ozaltunoglu (2011, pp. 85-121) from the Form to Receive Expert Opinions developed by Nacakc1 (2006, pp. 133-134) for his doctoral thesis study. Five point scales were used in the expert opinion form (Kaya, 2011, p. 102). The form was repeatedly examined by the resarcher to give its final shape. The Content Validity Index for all items was greater than 0.90 in the assessment of experts. For this reason, no changes have been made to the form.

\section{Data Analysis}

Percentage, mean and standard deviation were used as the descriptive statistical methods in the evaluation of the data. Kolmogorov-Smirnov and Shapiro-Wilk tests were applied to determine whether the groups were normally distributed. Non-parametric tests were chosen because of the limited number of students in the groups $(n=6)$. The Man Whitney-u test was used to compare quantitative longitudinal data between two independent groups. The Wilcoxon test was used to compare intra-group changes. The findings were evaluated at $95 \%$ confidence interval and 5\% significance level.

\section{FINDINGS}

\section{Findings and Comments on the First Hypothesis of the Study}

The pretest and posttest mean scores of the beginners' level group were calculated separately for posture and grip, right hand and left hand technique, performance and musicality dimensions, then the pretest and posttest changes regarding the total scores were presented in tabular form.

Table 3. Difference between the pretest and posttest scores of Beginners' Level Experimantal Group in terms of Posture and Instrumental Grip

\begin{tabular}{llllllll}
\hline & \multicolumn{3}{c}{ Pretest } & Posttest & N & Z & p \\
\cline { 2 - 4 } & Mean & Sd & Mean & SD & & & \\
Posture and Ins. Grip & 9,389 & 5,272 & 23,667 & 1,229 & 6 & $-2,201$ & 0,028 \\
\hline
\end{tabular}

As shown in Table 3, the difference between the arithmetic mean of the Wilcoxon test for the matched groups was statistically significant $(Z=-2,201 ; \mathrm{p}=0.028<0.05)$. The posture and grip pretest mean scores $(x=9,389)$ was lower than the posture and grip posttest $(x=23,667)$.

The differentiation of posture and grip scores of the beginners' level violin students for the posttest at the end of the experiment shows that distance violin teaching is effective in achieving the correct posture and 
instrumental grip. However, the level of this effect can only be revealed when compared to face-to-face training. It is still important, however, that the learners were able to attain the correct posture and grip without physical intervention of the teacher.

Table 4. Difference between the pretest and posttest scores of the Beginners' Level Experimental Group in terms of right hand and left hand tecnique

\begin{tabular}{|c|c|c|c|c|c|c|c|}
\hline \multirow[b]{3}{*}{ Right and Left Hand Technique } & \multicolumn{2}{|l|}{ Pretest } & \multicolumn{2}{|l|}{ Sontest } & \multirow[t]{2}{*}{$\mathrm{N}$} & \multirow[t]{2}{*}{$\mathrm{Z}$} & \multirow[t]{2}{*}{$\mathrm{p}$} \\
\hline & Mean & $\overline{\mathrm{Sd}}$ & Mean & $\overline{\mathrm{Sd}}$ & & & \\
\hline & 1,833 & 2,373 & 24,222 & 2,810 & 6 & $-2,201$ & 0,028 \\
\hline
\end{tabular}

As shown in Table 4, the difference between the arithmetic mean of the Wilcoxon test was found to be statistically significant for the matched groups in order to determine whether the beginners' level experimental group showed a significant difference between the right and left hand technique pretest and the right and left hand technique posttest $\mathrm{Z}=-2.201 ; \mathrm{p}=0.028 \& \mathrm{lt} ; 0.05)$. Right and left hand technique pre-test meanscores $(x=1,833)$ were lower than right and left hand technique post-test $(x=24,222)$.

It is shown that a difference existed between the students' right hand and left hand technique scores of the in favor of posttest at the end of the experimental period, and that teaching-learning activities and asynchronous learning were effective in acquiring the behaivors associated with the correct right hand and left hand technique. Because the right hand and left hand technique is not just a skill to be developed only wit in-class activities, it is necessary for the student to continue learning with the materials outside of the lesson and to do plenty of repetition. This dimension is very important for the students to establish a strong technical foundation. Therefore, it can be said that the difference related to this dimension was remarkable.

Table 5. Difference between the pretest posttest scores of beginners' level experimental group in terms of musicality

\begin{tabular}{|c|c|c|c|c|c|c|c|}
\hline & Pretest & & Posttest & & $\mathrm{N}$ & $\mathrm{Z}$ & $\mathrm{p}$ \\
\hline & Mean & $\mathrm{Sd}$ & Mean & $\mathrm{Sd}$ & & & \\
\hline Musicality & 0,000 & 0,000 & 19,444 & 1,544 & 6 & $-2,207$ & 0,027 \\
\hline
\end{tabular}

According to Table 5, as a result of the Wilcoxon test for the matched groups, the difference between the arithmetic mean was found to be statistically significant $(Z=-2,207 ; p=0.027<0,05)$. The musicality pretest mean scores $(x=0,000)$ is lower than the posttest $(x=13,778)$. Musicality is one of the most important topics in instrument education. Acquiring the behaviors and qualities important for good musicality requires the students to be involved in a very long and difficult process. Although the desired behaviors to be achieved at the beginners' level are limited, the change occured in this dimension can still be considered significant.

Table 6. Difference between the pretest posttest scores of beginners' level experimental group in terms ofperformance

\begin{tabular}{llllllll}
\hline & Pretest & \multicolumn{3}{c}{ Posttest } & N & Z & p \\
\cline { 2 - 5 } & Mean & Sd & Mean & Sd & & & \\
Performance & 0,000 & 0,000 & 19,444 & 1,544 & 6 & $-2,207$ & 0,027 \\
\hline
\end{tabular}

According to Table 6, as a result of the Wilcoxon test for the matched groups, the difference between the arithmetic mean was found to be statistically significant $(Z=-2,207 ; p=0.027<0,05)$. The performance pre-test mean scores $(x=0,000)$ is lower than the posttest $(x=13,778)$. 
Table 7. Difference between the pretest posttest total scores of beginners' level experimental group

\begin{tabular}{llllllll}
\hline & Pretest & \multicolumn{3}{c}{ Posttest } & $\mathrm{N}$ & $\mathrm{Z}$ & $\mathrm{p}$ \\
\cline { 2 - 4 } Total & Mean & $\mathrm{Sd}$ & Mean & $\mathrm{Sd}$ & & & \\
\hline
\end{tabular}

As shown in Table 7, the difference between the arithmetic mean of the Wilcoxon test for the matched groups was statistically significant $(\mathrm{Z}=-1,992, \mathrm{p}=0,046<0,05)$. The total pretest mean scores $(\mathrm{x}=11,222)$ was lower than the total post-test mean scores $(x=20,278)$.

When the arithmetic means for the total pre-test and total post-test scores of the experimental group were examined, no significant difference was found and the first hypothesis of research " $\mathrm{H}_{0}$ : There is no significant difference between Pre-test and posttest scores of the beginners' level experimental group" was rejected and the hypothesis "H1: There is significant difference between the pretest-posttest scores of the beginners'level experimental group." was confirmed. This difference exists for all dimensions and therefore, "distance violin instruction" can be considered an effective method in reaching the goals that are set during the beginners' level violin instruction.

\section{Findings and Comments Related to the Second Hypothesis of the Study}

Table 8. Difference between the pretest and posttest scores of beginners' level control group in terms of posture and instrument grip

\begin{tabular}{|c|c|c|c|c|c|c|c|}
\hline & Pretest & & Posttest & & $\mathrm{N}$ & $\bar{Z}$ & $\mathrm{p}$ \\
\hline & Mean & $\overline{\mathrm{Sd}}$ & Mean & $\mathrm{Sd}$ & & & \\
\hline Posture and Ins. grip & 10,278 & 4,828 & 23,667 & 1,033 & 6 & $-2,201$ & 0,028 \\
\hline
\end{tabular}

As can be seen in Table 8 , as a result of the Wilcoxon test for the matched groups, the difference between the arithmetic mean was found to be statistically significant $(Z=-2,201, p=0,028<0.05)$. The posture and grip pretest mean score $(x=10,278)$ is lower than the posttest $(x=23,667)$.

Table 9. Difference between the pretest and post-test scores of beginners' level control group in terms of right hand and left hand technique

\begin{tabular}{llllllll}
\hline & Pretest & \multicolumn{3}{c}{ Posttest } & N & Z & p \\
\cline { 2 - 5 } & Mean & Sd & Mean & Sd & & & \\
Right H. and Left H. Tech. & 1,167 & 1,090 & 24,833 & 2,681 & 6 & $-2,201$ & 0,028 \\
\hline
\end{tabular}

According to Table 9, the difference between the arithmetic mean of the Wilcoxon test for the matched groups in order to determine whether the control group had significant difference between the right and left hand technique pretest and the right and left hand techniques posttest was statistically significant $(Z=2,201$; $\mathrm{p}=0.028 \& \mathrm{lt} ; 0.05)$. The mean score for the right hand and left hand technique pretest $(\mathrm{x}=1,167)$ is lower than that of the posttest $(\mathrm{x}=24,833)$.

Table 10. Difference between the pretest -posttest scores of beginners' level control group in terms of performance

\begin{tabular}{|c|c|c|c|c|c|c|c|}
\hline \multirow[b]{3}{*}{ Performance } & \multicolumn{2}{|l|}{ Pretest } & \multicolumn{2}{|l|}{ Posttest } & \multirow[t]{2}{*}{$\mathrm{N}$} & \multirow[t]{2}{*}{ Z } & \multirow[t]{2}{*}{$\mathrm{p}$} \\
\hline & Mean & $\overline{\mathrm{Sd}}$ & Mean & $\overline{\mathrm{Sd}}$ & & & \\
\hline & 0,000 & 0,000 & 19,222 & 1,695 & 6 & $-2,201$ & 0,028 \\
\hline
\end{tabular}


According to Table 10, as a result of the Wilcoxon test for the matched groups, the difference between the arithmetic mean was found to be statistically significant $(\mathrm{Z}=-2,201, \mathrm{p}=0,028<0,05)$. The pretest mean scores for performance $(\mathrm{x}=0,000)$ was lower than the posttest $(\mathrm{x}=19,222)$.

Table 11. Difference between the pretest and posttest scores of beginners' level control group in terms of musicality

\begin{tabular}{|c|c|c|c|c|c|c|c|}
\hline & Pretest & & Posttest & & $\mathrm{N}$ & $\bar{Z}$ & $\mathrm{p}$ \\
\hline & Mean & $\mathrm{Sd}$ & Mean & $\mathrm{Sd}$ & & & \\
\hline & 0,000 & 0,000 & 13,833 & 0,937 & 6 & $-2,226$ & 0,026 \\
\hline
\end{tabular}

According to Table 11, as a result of the Wilcoxon test for the matched groups comparing beginners' level pretest and posttest scores in terms of musicality, the difference between the arithmetic mean was found to be statistically significant $(Z=-2,226, p=0,026<0,05)$ The pretest mean scores for musicality $(x=0,000)$ was lower than the posttest $(\mathrm{x}=13,833)$.

Table 12. Difference between the pretest -posttest total scores of beginners' level control group

\begin{tabular}{|c|c|c|c|c|c|c|c|}
\hline & Pretest & & Posttest & & $\mathrm{N}$ & Z & $\mathrm{p}$ \\
\hline & Mean & $S d$ & Mean & $S d$ & & & \\
\hline Total & 11,444 & 5,447 & 20,389 & 1,524 & 6 & $-2,201$ & 0,028 \\
\hline
\end{tabular}

As shown in Table 12, the difference between the arithmetic mean of the Wilcoxon test was found to be statistically significant $(Z=-2,201, p=0.028<0,05)$ for the matched groups in order to determine whether the total pretest and the total posttest averages of the beginners' level control group had a significant difference. The total mean score fort he pre-test $(x=11,444)$ is lower than the posttest $(x=20,389)$. This difference in posture and gripping, right hand and left hand technique, performance, musicality dimensions and is a result which could be naturally expected in face to face violin instruction. Given the arithmetic means of the total pretest and total posttest scores of the control group, the hypothesis, H0: "There is no significant difference between the pretest-posttest scores of the beginners' level control group" was rejected and the hypothesis"H1: There is a significant difference between the pretest-posttest scores of the beginners' level control group " was confirmed.

\section{Findings and Comments Related to the Third Hypothesis of the Study}

Table 13. Beginners' level experimental and control groups' pretest and post test mean scores in terms of posture and instrument grip

\begin{tabular}{|c|c|c|c|c|c|c|}
\hline \multirow[t]{2}{*}{ Groups } & \multicolumn{2}{|c|}{ Experimental } & \multicolumn{2}{|l|}{ Control } & \multirow[t]{2}{*}{ MW } & \multirow[t]{2}{*}{$\mathrm{p}$} \\
\hline & Mean & $\mathrm{Sd}$ & Mean & $\mathrm{Sd}$ & & \\
\hline Pretest Posture-Ins.Grip & 9,389 & 5,272 & 10,278 & 4,828 & 14,500 & 0,575 \\
\hline Posttest Posture-Ins. Grip & 23,667 & 1,229 & 23,667 & 1,033 & 18,000 & 1,000 \\
\hline
\end{tabular}

Results of the Mann Whitney- $\mathrm{U}$ test used to compare the students' pretest and post test scores related to posture and instrumental grip according to the group variable showed no significant difference between the groups' mean scores. 


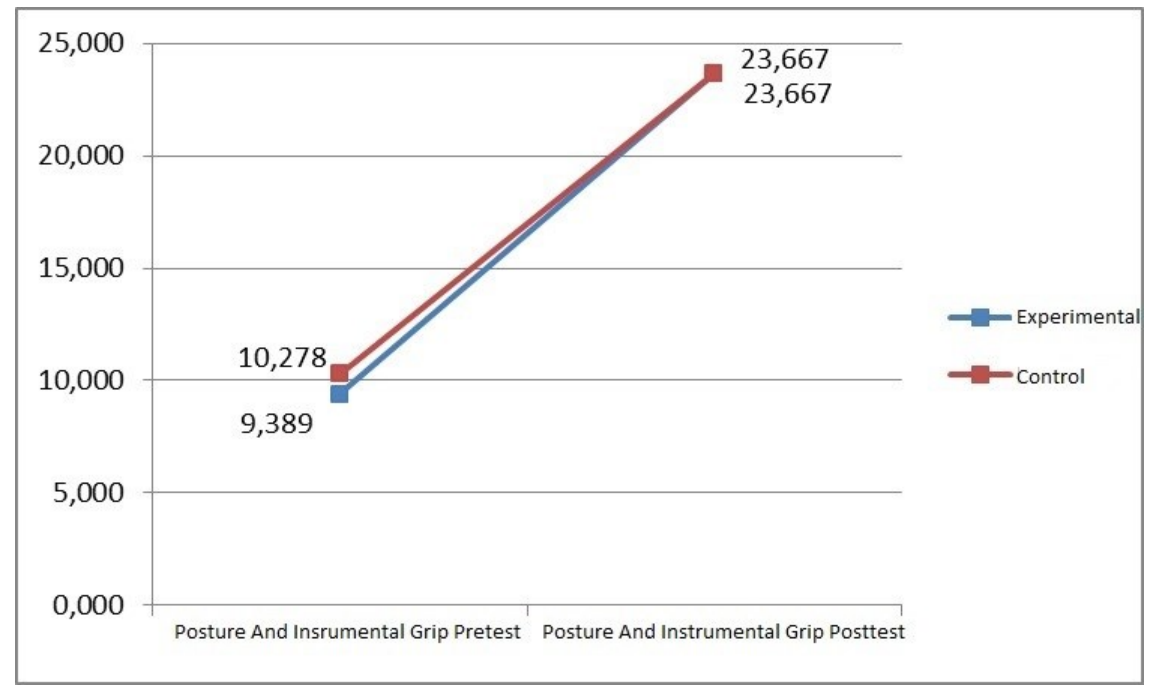

Figure 1. The Diagram related to the Pre-test and post-test scores of beginners' level experimental and control groups in terms of posture and instrument grip.

As seen in Figure 1, the two groups have equal posttest scores for posture and instrumental grip. It can be concluded that, there is no difference between distance and face-to-face instruction in terms of acquiring the beginners' level target behaviors related to correct posture and correct instrumental grip.

Table 14. Beginners'level experimental and control groups' pretest and posttest mean scores in terms of right hand and left hand technique

\begin{tabular}{lllllll}
\hline & \multicolumn{2}{l}{ Experimental } & \multicolumn{2}{c}{ Control } & \multirow{2}{*}{ MW } & $\mathrm{p}$ \\
\cline { 2 - 5 } & Mean & Sd & Mean & Sd & & \\
Pretest - Right and Left Hand T. & 1,833 & 2,373 & 1,167 & 1,090 & 16,000 & 0,746 \\
Posttest - Right and left Hand T. & 24,222 & 2,810 & 24,833 & 2,681 & 15,000 & 0,630 \\
\hline
\end{tabular}

As shown in Table 14, there was no statistically significant difference between the group means as a result of the Mann Whitney-U test to determine whether the mean of the students' right and left hand technique pretest, right hand and left hand technique posttest scores were significantly different for the group variable $(\mathrm{p}>0.05)$.

The right hand and left hand technique posttest scores of the groups were found to be very close. The right hand and left hand technique of the experimental group is not statistically significant, although the posttest score of the experimental group was slightly lower the difference between the groups was not significant. This could be interpreted as, in teaching the target behaviors associated with right hand and left hand technique, distance violin instruction can be almost as effective as face to face instruction. 


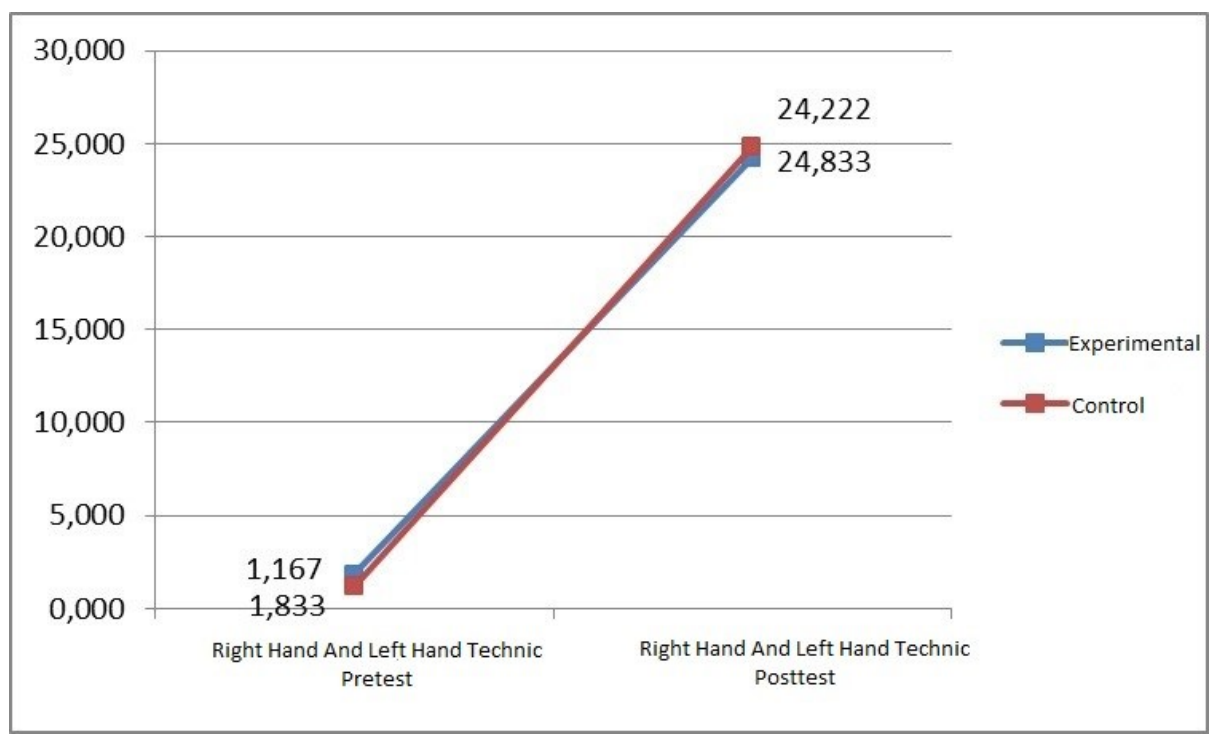

Figure 2. The Diagram related to the pre-test and post-test scores of beginners' level experimental and control groups in terms of right hand and left hand technique.

Table 15. Beginners'level experimental and control groups' pretest and post test mean scores in terms of performance

\begin{tabular}{|c|c|c|c|c|c|c|}
\hline & \multicolumn{2}{|c|}{ Experimental } & \multicolumn{2}{|l|}{ Control } & \multirow[t]{2}{*}{ MW } & \multirow[t]{2}{*}{$\mathrm{p}$} \\
\hline & Mean & $\mathrm{Sd}$ & Mean & $\mathrm{Sd}$ & & \\
\hline Pretest - Performance & 0,000 & 0,000 & 0,000 & 0,000 & 18,000 & 1,000 \\
\hline Posttest - Performance & 19,444 & 1,544 & 19,222 & 1,695 & 16,000 & 0,746 \\
\hline
\end{tabular}

According to Table 15, as a result of Mann Whitney-U test used to determine whether the average of performance pre-test and performance post-test scores of beginner students showed a significant difference for the group variable, the difference between groups was not statistically significant $(p>0,05)$. The fact that students of distance learning and face to face learning performed very closely at the end of the process may indicate the efficiency of distant violin instruction.

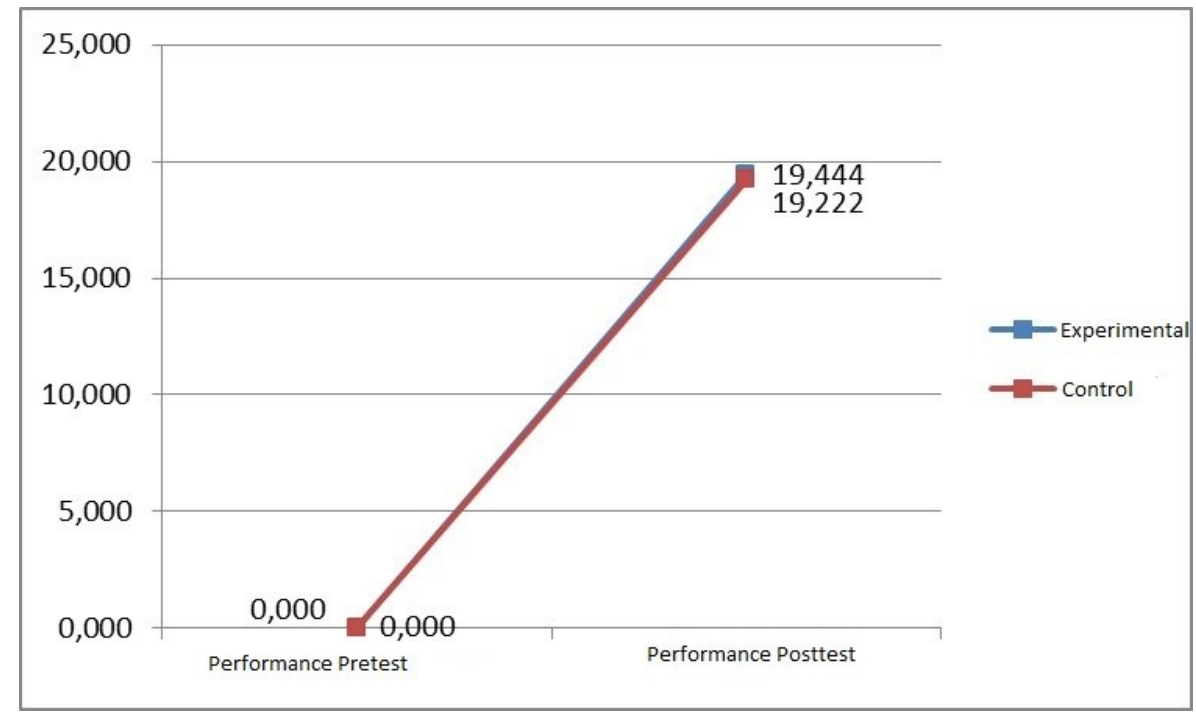

Figure 3. The Diagram related to the Pre-test and post-test scores of beginners' level experimental and control groups in terms of performance. 
Table 16. Beginners' level experimental and control groups' pretest and post test mean scores in terms of musicality

\begin{tabular}{|c|c|c|c|c|c|c|}
\hline & \multicolumn{2}{|c|}{ Experimental } & \multicolumn{2}{|l|}{ Control } & \multirow[t]{2}{*}{ MW } & \multirow[t]{2}{*}{$\mathrm{p}$} \\
\hline & Mean & $\mathrm{Sd}$ & Mean & $\mathrm{Sd}$ & & \\
\hline Pretest - Musicality & 0,000 & 0,000 & 0,000 & 0,000 & 18,000 & 1,000 \\
\hline Posttest -Musicality & 13,778 & 1,721 & 13,833 & 0,937 & 18,000 & 1,000 \\
\hline
\end{tabular}

According to Table 16, the difference between group averages of Mann Whitney-U test was not statistically significant $(\mathrm{p}>0,05)$. Pre-test and post-test mean scores of beginners' level violin students showed a significant difference in terms of musicality for the group as the variable.

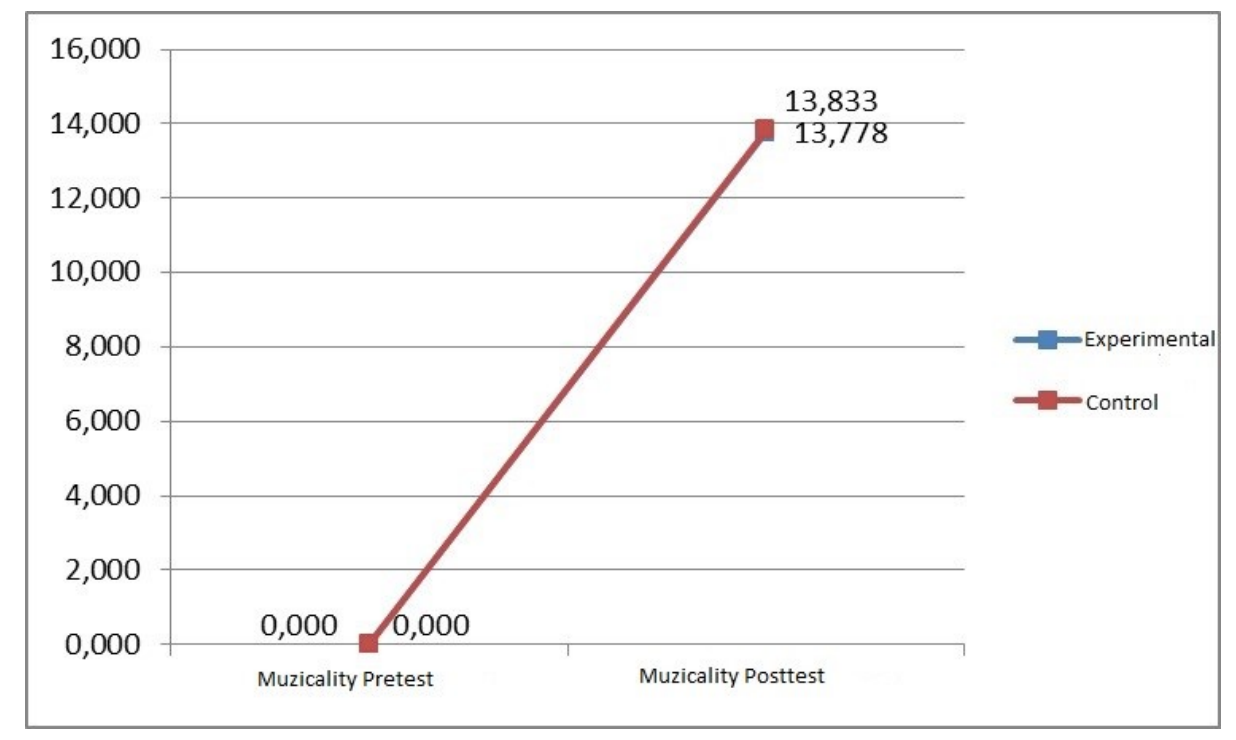

Figure 4. The Diagram related to the Pre-test and post-test scores of beginners' level experimental and control groups in terms of musicality

Table 17 shows the average of total pre-test and post-test scores according to the groups. $(p>0,05)$ The result of the Mann Whitney- $U$ test to determine whether the pre-test and total post-test averages of the initial violin students had a significant difference fort he group as a variable showed no significant differecne statistically. This could be interpreted as, as well as synchronous courses asynchronous courses and materials are effective during distance education.

Table 17. Beginners'level experimental and control groups'means of total pretest and post test scores

\begin{tabular}{lllllll}
\hline & \multicolumn{3}{l}{ Experimental } & Control & MW & $\mathrm{p}$ \\
\cline { 2 - 5 } & Mean & Sd & Mean & Sd & & \\
Pretest - Total & 11,222 & 7,536 & 11,444 & 5,447 & 16,000 & 0,749 \\
Posttest - Total & 20,278 & 1,729 & 20,389 & 1,524 & 17,000 & 0,873 \\
\hline
\end{tabular}




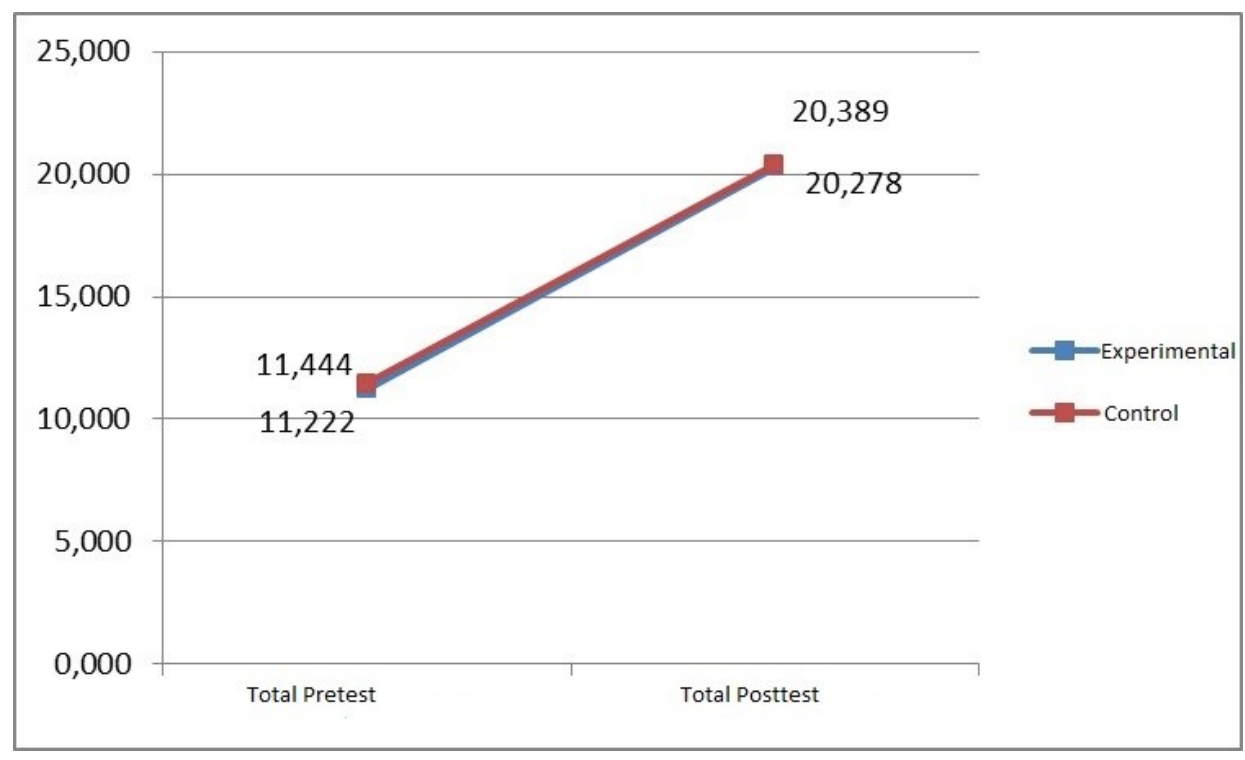

Figure 5. The Diagram related to the Pre-test and Post-test total scores of beginners' level experimental and control groups

When the average values of total pretest and total posttest scores of beginners' violin students are examined, it is seen that the hypothesis H0 "There is not a significant difference between pretest and posttest mean scores of control group and control group" was confirmed. These findings were interpreted as the fact that in teaching violin at the beginners' level, both instructional methods are very close to each other beginner violin students wer

\section{CONCLUSION, DISCUSSION AND RECOMMENDATIONS}

\section{Results}

The findings of this study, in which the efficiency of distance learning model in beginners' level violin instruction was investigated, the following results were achieved:

$>$ There was a statistically significant difference between pretest and posttest scores of initial group ( $\mathrm{p}=0,046<0,05)$ in favor of posttest $(\mathrm{x}=20,278)$.

$>$ There was a significant difference between pretest and posttest scores of the control group $(\mathrm{p}=0,028<0,05)$. This difference is in favor of the posttest $(\mathrm{x}=20,389)$.

$>$ There was no significant difference between the mean of the pre-test scores of the beginners' level experimental and control groups $(\mathrm{p}=0,749)$ and the post-test scores of the groups ( $\mathrm{p}$ $=0,873$ ). This result shows that no differences found between face-to-face instruction and distance learning within the context of acquiring basic skills

\section{Discussion}

Much research has been done on distance education. While the effectiveness of distance education was observed in some studies, there are other studies favored face-to-face training. In this section, comparisons have been made between the results of this study and the results of other studies on distance learning. In a study conducted by Yavuz (2015) to compare the average scores of the students who participated in distance education related to their courses and the teaching materials, the face-to-face in-service training group's scores were slightly higher than the average scores of the distance in-service training group, but the difference wasn't statistically different. In addition, Although Alberich-Artal and Sangra (2012), suggested that information and communication technologies do not make enough contributions to individual learning and for this reason, the traditional model had to be repeatedly used and Dammers (2009) showed that online trumpet lessons are at a basic level of functioning. The results of the study conducted by Doggett (2008) to 
compare face-to-face teaching with video conferencing were also similar. As a result of Dogget's research, no significant difference found between teaching by face-to-face instruction and videoconferencing. MacLaughlin, Supernaw and Howard (2004) did not found any difference between the success of students attending distance and face-to-face classes.

Barry (2003) indicated that education supported by web-based resources contributed to the development of students. Shoemaker and Stam (2010) have shown that learning occurs effectively when synchronous and asynchronous learning modes are used together. In this research designed for remote violin teaching, the effectiveness of distance education was demonstrated by using synchronous and asynchronous communication together. Therefore, Shomaker and Stam's research results are similar to those of this study conducted with violin students. Kangasluoma (2010) stated that the lessons were prepared carefully and that the technical equipment did not cause any problem in remote violin teaching when it worked correctly and well. Percivall (2008) found that the program MEAWS, which was developed in the context of remote violin teaching, is functional for beginner students. On the other hand, Maki (2001) stated that during the distance education, there was a problem with voice and picture transmission in his research. However, she points out that there is no difference between distance education and face-to-face education in courses such as Music History and Music Theory. Generally speaking; Doggett (2008), Percivall (2008), MacLaughlin, Supernaw and Howard (2004), and Yavuz (2015), Alberich-Artal and Sangra (2012), Shoemaker and Stam Barry's (2003) research results support the results of this research.

There are also studies in the literature that show that distance education is more effective than face-to-face teaching. In the researches of Sever (2014), Ryder (2004), Atıcl (2000) and Lim-Fernandes (2000), distance education was found to be more effective than face-to-face teaching. Looking at the results of Topalak's research (2016), significant differences were found in favor of the experimental group in the dimensions of verbal learning and playing face-to-face, playing with correct rhythm, playing an acceptable tempoda, culling, nuance dynamic, track integrity and technical behavior. However, there was no significant difference in any dimension when looking at the achievements of the students in distance learning of violin. For this reason, Topalak's (2016) research results do not coincide with the results of this study in which the effects of distance learning of violin are explored. According to the results of this research, although there is no difference between distance education and face-to-face education in any of the fundamental dimensions of violin learning, it has been shown that distance violin instruction has a positive effect on the learners' violin learning.

Brandstrom, Wiklund and Lundstrom (2012) stated that videoconferencing requires more intensive and comprehensive planning than face-to-face teaching, suggesting that distance education may be complementary to face-to-face training. Because of the delays in synchronous communication, there is no good education due to the inability of sound transmission to communicate properly. In synchronous communication, the quality of communication can be reduced for various reasons. The videos prepared for the students to keep their studies asynchronously healthy are considered important in terms of not reflecting the problems experienced in synchronous communication to the learning of the student.

Distance education researches are not just about comparing distance education to face-to-face instruction. There are also researches on different technologies used in distance education. Riley, MacLeod, and Libera (2014) used a platform called LOLA (Low Latency Audio Video), as well as Polycom and Skype platforms, to study a classic masterclass, jazz lesson, and violin lesson. It turns out that LOLA is more effective than the other two platforms.

It is thought that the wide range of results in the researches in distance education is related to many factors such as technological infrastructure, geographical conditions, reasons for the characteristics of the study group, not just about the curriculum. It is a fact that distance education is carried out healthier as technology 
advances. As the speed of Internet and data transfer increases day by day and new technologies such as virtual reality are considered to be developed, more positive results regarding distance education can be obtained in the near future.

\section{Suggestions}

Taking the results obtained into consideration, the following recommendations are given:

$>$ Distance education and face-to-face instruction can be used interchangeably when needed. Thus equal opportunities can be accessed regardless of environmental, regional and individual differences.

$>$ Realization of such researches with larger working groups can give more positive results for both healthier and distance education.

$>$ Distance learning models for other instruments can be developed.

\section{BIODATA and CONTACT ADDRESSES of AUTHORS}

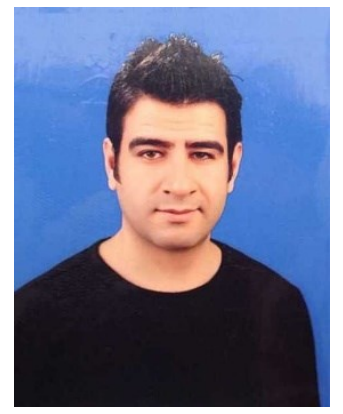

Dr. Soner OKAN was born in Elazig, in 1980. After the completion of his primary, secodary and high school education in here in 2002, he graduated from Suleyman Demirel University, Burdur Faculty of Education, Music Education Program. For six years, he worked as a music instructor in various public schools. In 2008 he assigned to Diyarbakır High School of Fine Arts and worked there as a violin instructor for 4 years. In 2010, he obtained his Master's Degree from Mehmet Akif Ersoy University, Institute of Social Sciences and in 2012 he was assigned to Dicle University, State Conservatory as a violin Instructor. In the same year he obtained his Phd from İnonu University, Institute of Educational Sciences. He still continues his duty at Kahramanmaras Sutcu Imam University.

\section{Soner OKAN}

Faculty of Fine Arts, Music Department, Kahramanmaras Sutcu Imam University, Address: Kahramanmaras Sutcu Imam University, Avsar Campus, 46100

Onikisubat, Kahramanmaras, TURKEY

Phone: +90 5066028284

E-mail: sonerokan@hotmail.com

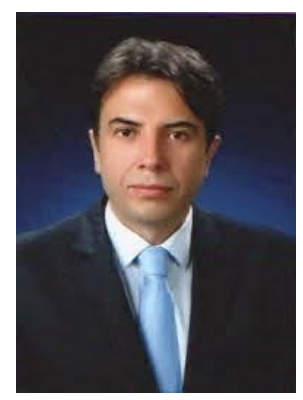

Dr. Hasan ARAPGIRLIOGLU was born in Kahramanmaras in 1971. He was introduced to music at an early age and took part in various music groups during his primary and secondary education. In 1990, he graduated from the Music Department of Gazi University. In the same year, she earned her MA degree in the same year. She completed her master's degree in 1997 and $\mathrm{PhD}$ in music education in 2002. He became Assistant Professor in 2003, Associate Professor in 2007 and Professor in 2012. T.S.K. He was in the harmony team of Harmony Band. He worked as an orchestra conductor and cello performer in the ensembles such as Baskent Chamber Orchestra, Gazi University Academic Chamber Orchestra, Inonu University Academic Chamber Orchestra and Youth Symphony Orchestra. U.S. In 2010, the Academy of Humanities (NEH-u.s. national Endovement for Humanities) Turkey History and Culture Blues as scholarship, international same year N.A.T.O. She took place as an expert invited researcher and trainer in music therapy workshop. European Congress on Science, Art \& Culture (ECSAC'17 - Prague). He made studies in the field of Recording Technologies. Cihat Askın, Sweden Tango Orchestra, Kerem Gorsev Jazz Trío, Yildiz Ibrahimova-Grup Markanja, Suna Kan-Cana Gurmen, Marmara Trio, Anadolu University The Symphony Orchestra, Holger Mantey received studio and live performance recordings. 2011 at the University of Massachusetts Ensemble Recording Techniques, in 2013 in Portugal-Castelo Branco Music Department Chamber Music, in 2014 Hungary Szeged University. He gave lessons in Music Technology in Music Department. He gave concerts in New York, Boston, New Jersey, 
Memphis, Austria-Lins, Budapest, Hong-Kong and Prague. He worked as Dean of Faculty of Fine Arts of Kırlkkale University and dean of Faculty of Fine Arts of İnonu University. He is currently a member of the Akdeniz University Antalya State Conservatory Orchestra Conducting and Composition Department.

\section{Hasan ARAPGIRLIOGLU}

Antalya State Conservatory, Composition and Conducting

Address: Akdeniz Universitesi, Dumlupinar Bulvari 07058 Kampus,

Konyaalti / Antalya

E-mail: ahasan@akdeniz.edu.tr

\section{REFERENCES}

Alberich-Artal, E. ve Sangrà A. (2012). Virtual virtuosos: a case study in learning music in virtual learning environments in Spain. European Journal of Open, Distance and ELearning. Retrieved 11.03.2016 from http://www.eurodl.org/?p=current\&sp=full\&article=477

Barry, N. H. (2003). Integrating web based learning and instruction into a graduate music education research course: an exploratory study. Journal of Technology in Music Learning, 2(1), 2-8.

Brändstrom, S, Wiklund, C. ve Lundstrom, E. (2012). Developing distance music education in Arctic Scandinavia: electric guitar teaching and master classes. Music Education Research, (14) 4, 448456.

Dammers, R. J. (2009). Utilizing internet-based videoconferencing for Instrumental music lessons. Applications of Research in Music Education November 2009, 28(1), 17-24.

Doggett, A. M. (2008). The videoconferencing classroom: what do students think? Journal of Industrial Teacher Education, 44(4), 29-41.

MacLaughlin E. J., Supernaw R. B. ve Howard K. A. (2004). Impact of distancelearning using videoconferencing technology on student performance. Am JPharm Education, 68(3).

Kangasluoma, M. (2010). Viulua verkossa. Johdatus viulunsoiton etäopetukseen. Opinnäytetyo. Musiikin koulutusohjelma. Oulun seudun ammattikorkeakoulu. Violin on the WebIntroduction to Violin Distance Education. A Bachelor`s Thesis in Music Education, Oulu University of Applied Sciences.

Lim-Fernandes, M. A. (2000), “Assessing the Effectiveness of Online Education', PhD Thesis, San Francisco Golden Gate University, USA.

Percival, G. K. (2008). Computer-assisted musical instrument tutoring with targeted exercises (Doctoral dissertation), University of Victoria, Canada.

Riley H., MacLeod B. M. ve Libera M. (2014). Low latency audio video: potentials for collaborative music making through distance learning. National Association for Music Education. Retrieved 01.12.2016, from upd.sagepub.com

Ryder, O. C. (2004). The use of internet-based teaching strategies in teaching vocal anatomy, function, and health to high school choral music students, and its effect on student attitudes and achievement. Shenandoah Conservatory, ABD.

Sever, G. (2014). The Application of Flipped Learning Model on Individual Violin Lessons [Bireysel calg1 keman derslerinde cevrilmis ogrenme modelinin uygulanmasi], Qualitative Research Journal in Education [Egitimde Nitel Arasttrmalar Dergisi], 2(2), 27-41.

Shoemaker, K. ve Stam, G. V. (2010). e-Piano, A Case of Music Education via e-Learning in Rural Zambia. Web Science Conf. 2010, April 26-27, Raleigh, NC, USA. 
Taninmis, G. E. (2013). The Effect of the musical artivulation education on the violin students' musical articulation ability at Gazi University Gazi Education Faculty Fine Arts Education Deparment Music Education Branch [G. U. Gazi Egitim Fakultesi G. S. E. bolumu muzik egitimi anabilim dali keman ogrencilerinin aldiklari keman egitiminde karsilastiklari sorunlar ve sorunlari cozmede izledikleri yollar.] International Periodical for The Languages, Literature and History of Turkish or Turkic, 8(6), 707-71.

Tarkum, E. (2006). The Role Factors of Violin Instruction [Keman ogretiminde rol oynayan faktorler.] ZKU Social Science Journal IZKU Sosyal Bilimler Dergisij, 2(4), 169-173.

Topalak, S. (2016). The Effect of Flipped Learning Model in Basic Level of Piano Instruction. [Cevrilmis ogrenme modelinin baslangıc seviyesi piyano ogretimine etkisi.] Unpublished Dissertation [Yayımlanmamıs Doktora Tezi]. Inonu University Education Science Institute [İnonu Universitesi Egitim Bilimleri Enstitusu], Malatya.

Yavuz, C. (2015). Comparison of distance in-service learning and face-to-face in-service learning in terms of the success of the learners and the persistence of learning. [Uzaktan ve yuz yuze hizmet ici egitimin ogrenenlerin basarisi ve ogrenmenin kaliciligi acisindan karsilastirilmasi.] Unpublished Master Thesis [Yayımlanmamis, Yuksek Lisans tezi.] Gazi University Education Science Institute [Gazi Universitesi, Egitim Bilimleri Enstitusu], Ankara. 